\title{
Occurrence of asbestos in soils: state of the art
}

\author{
${ }^{1}$ Department of Biological, Geological and Environmental Sciences, University of Catania, Corso Italia, 55, 95129 Catania CT, Italy; \\ *Corresponding author, E-mail: claudia.ricchiuti@unict.it,punturo@unict.it \\ ${ }^{2}$ Department of Biology, Ecology and Earth Sciences, University of Calabria, Via Pietro Bucci, I-87036 Rende, Italy
}

(Received: February 1, 2020; Revised accepted: May 15, 2020)

https://doi.org/10.18814/epiiugs/2020/0200s06

In the last decades, it has been widely demonstrated the risk to human health related to asbestos fibres exposure. Many studies have mainly focused on the mineralogical and geochemical characterization of ophiolites (i.e., serpentinite and metabasite rocks) since they are the main lithotypes associated with Naturally Occurring Asbestos (NOA). Nevertheless, derivative soil from these rocks inherits the mineralogical and geochemical composition of bed rock and may contain hazardous fibres, thus making its examination necessary as well. This paper provides a summary of asbestos-containing soils investigation worldwide with the purpose of providing an overview of the data obtained so far. To this aim, the most relevant available literature, testifying the presence of fibrous minerals in soils have been considered. This allowed the global territory mapping in order to depict the distribution of natural asbestos in soils worldwide.

\section{Introduction}

Asbestos is a term used to indicate six fibrous silicate minerals belonging to serpentine (i.e., chrysotile) and amphibole (i.e., tremolite, actinolite, anthophyllite, amosite that is the fibrous-asbestiform variety of grunerite also known as brown asbestos, and crocidolite that is the fibrous-asbestiform variety of riebeckite, commercially known as blue asbestos; Gualtieri et al., 2017) super-group (WHO, 1986; NIOSH 2008; Ballirano et al., 2017). These minerals have been widely exploited to create Asbestos-Containing Materials (ACMs) due to their physical properties (Bloise et al., 2017a, 2018a, b; Bloise 2019a).

The term NOA means the asbestos fibres present in rocks (i.e., serpentinite or altered ultramafic rocks) and soils, referring to those that have not been extracted for commercial purposes (Bloise et al., 2008; Harper, 2008; Pugnaloni et al., 2013; Belluso et al., 2020; Bailey 2020a,b; Cahill 2020; Cagnard et al., 2020; Erskine 2020; Gualtieri 2020; Léocat 2020; Pierdzig 2020; Wroble et al., 2020). The natural asbestos occurrences is widespread in the environment, some examples include chrysotile deposits in Ural Mountains in the Russian Federation (Ross and Nolan, 2003), Appalachian Mountains (USA), Canada (Virta, 2006) and also in India, China, Italy, South Africa, Australia, Greece, Cyprus (Ross and Nolan, 2003) and other countries. Figure 1a, shows a global map with the main asbestos mines. The most frequent asbestos occurring form is chrysotile, whose fibres are normally found as veins in serpentine rocks, followed by anthophyllite, crocidolite, tremolite, actinolite and amosite (Virta, 2002; Bloise et al., 2019b).

Human activity and weathering processes may disturb NOA and provoke the dispersion of fibres, potentially inhalable, in the environment. Many studies confirmed that death from lung diseases can be associated with environmental exposure to asbestos (IARC, 2009). In fact, the risk to human health is represented by the inhalation of asbestos fibres that penetrate in the lungs and may cause cancer pathologies. It is worth noting that, fibrous minerals such as, erionite, ferrite fluoro-edenite, antigorite (Gianfagna et al., 2003; Cardile et al., 2007; Ballirano et al., 2018a,b; Gualtieri et al., 2018; Petriglieri et al., 2020) and others, may have toxic effects as asbestos fibres and, if inhaled, can be dangerous.

To date, many studies are based on the knowledge of natural asbestos in rocks whereas much less literature refers to asbestos-bearing soils. Asbestos in soils may be found for: i) improperly removal of Asbestos-Containing Materials; ii) proximity to asbestos factory/mine; iii) inheritance from mother rocks (natural occurrences).

In this scenario, this work aims to provide an overview about the presence of asbestos fibres in soils worldwide pointing to improve knowledge of asbestos global issue. Therefore, the most relevant study from various disciplines (i.e., geology, mineralogy, medicine, etc.) that testified the presence of asbestos in soil were hereby considered, thus making it available an overview of the data obtained so far and providing a contribution to the mapping of the territory (Fig. 1b).

Because of considerable asbestos-related diseases (Skinner et al., 1988) all of the six asbestos minerals are considered toxic to human health and therefore regulated by law. However, currently only in 67 over 195 countries (34\%) in the world the use of regulated asbestos minerals is restricted (Table 1). Since many studies provide the epidemiological evidence that asbestos crocidolite and tremolite are apparently more dangerous than chrysotile (Hodgson et al., 2000), many countries employ it since this is considered a "safe use" for industrial purposes. For example, Russia is the biggest producer in the world (tons/year) followed by China, Brazil, Kazakhstan and India as shown by the 2014 (chrysotile) asbestos trade data (Gualtieri, 2017).

The different global use of asbestos is due to the various political and economic situation of countries and it is constantly changing. For instance, some countries like Canada and Colombia have recently changed their regulations relatively to asbestos exploitation and use. Indeed, in 
Colombia the new law is taking effect on January 1st, 2021 with five years transition period for companies currently using asbestos minerals. The ban prohibited the mining, commercialization and distribution of all asbestos types including its export. In the case of Canada, despite asbestos fibres have been recognized as hazardous to human health and well-being (World Health Organization's International Agency) for more than 30 years, Canada remained one of the major exporter of this material until 2011. The federal Prohibition of Asbestos and Products Containing Asbestos Regulations (Regulations: SOR/ 2018-196) came into force in Canada on January 2019, prohibiting the import, sale and use of asbestos as well as of products containing asbestos. However, there are certain exceptions such as asbestos contained in household product intended for personal use or in a military equipment (IBAS, 2019).

Even in the scientific community a division is noted: some scien- tists promote the "safe use" of chrysotile and assume that it has little potential for causing mesothelioma (e.g., Liddell et al., 1997; McDonald et al., 1997; Camus, 2001) whereas others are totally opposed to this and claim that all six asbestos types may induce lung diseases if inhaled (Skinner et al., 1988; Yarborough, 2007). Therefore, the International Agency for Research on Cancer define them belonging to Group 1 "substance carcinogenic to humans" (IARC, 2012).

It is difficult to univocally define the relationship (cause-effect) between disease and exposure to different fibres types because of the variability in the chemistry, size, molecular arrangement, surface activity (Pollastri et al., 2014; Bloise et al., 2016b) of mineral fibres. For instance, one hypothesis of higher toxicity of amphiboles compared to chrysotile is based on the behavior of fibres in the lungs. In particular, unlike the amphiboles that are more durable and remain in the lungs for a long time, chrysotile dissolves reasonably quickly due to its low biodura-
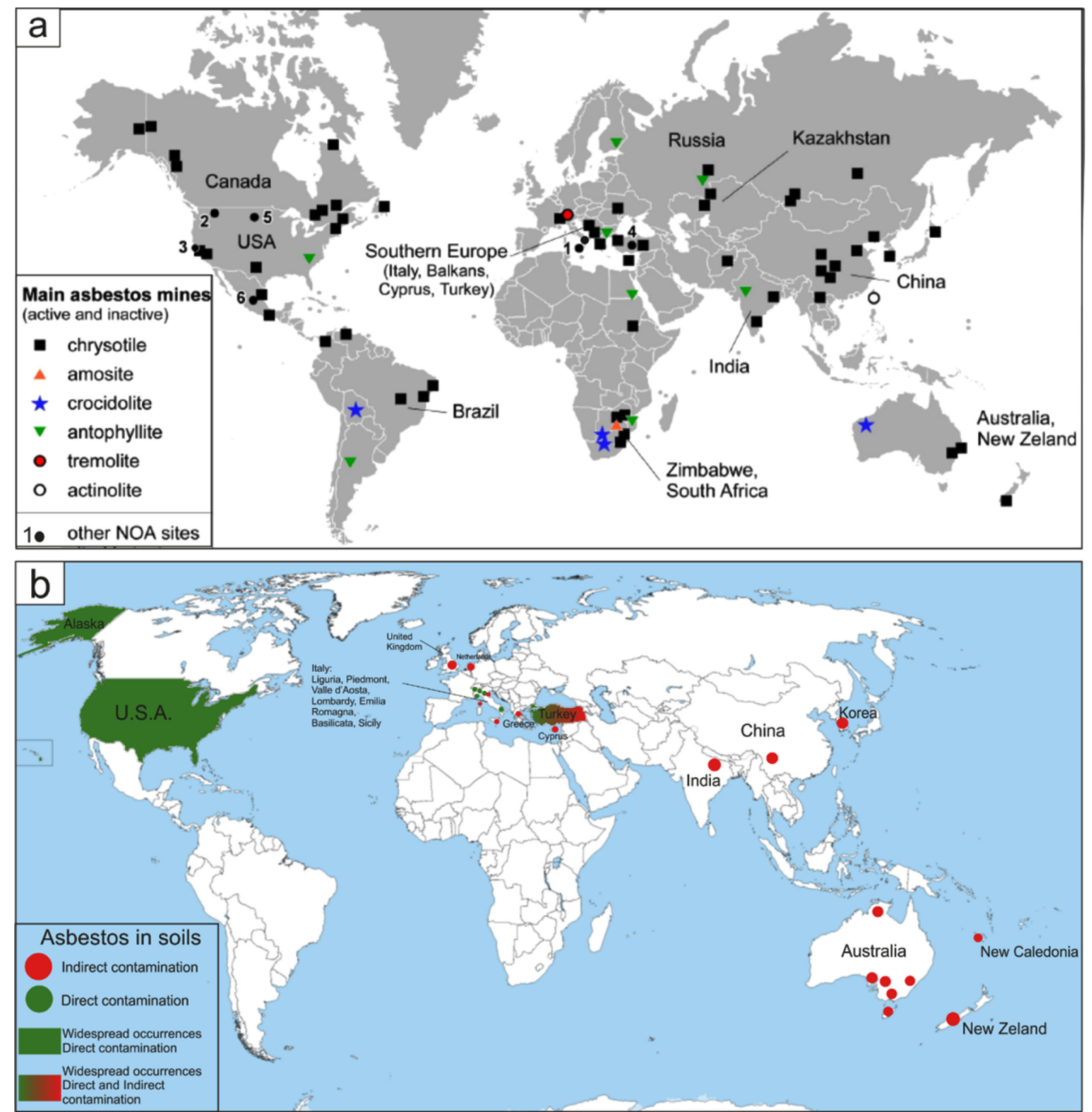

Figure 1. a) global map with the main asbestos mines (active and inactive), modified after Virta 2002; b) global map with the asbestos-containing soil at the state of the knowledge. 
Table 1. Exemptions for minor uses are permitted in some countries listed; however, all countries listed must have banned the use of all types of asbestos. List compiled by Laurie Kazan-Allen and modified and revised in July 15, 2019 (http://www.ibasecretariat.org/alpha_ban_list.php)

\begin{tabular}{|c|c|c|c|c|}
\hline \multicolumn{5}{|c|}{ National Asbestos Bans } \\
\hline Algeria & Czech Republic & Iraq & Mauritius & Seychelles \\
\hline Argentina & Denmark & Ireland & Monaco & Slovakia \\
\hline Australia & Djibouti & Israel & Mozambique & Slovenia \\
\hline Austria & Egypt & Italy & Netherlands & South Africa \\
\hline Barain & Estonia & Japan & New Caledonia & Spain \\
\hline Belgium & Finland & Jordan & New Zeland & Sweden \\
\hline Brazil & France & Korea (South) & Norway & Switzerland \\
\hline Brunei & Gabon & Kuwait & Oman & Taiwan5 \\
\hline Bulgaria & Germany & Latvia & Poland & Turkey \\
\hline Canada & Gibraltar & Liechtenstein & Portugal & United Kingdom \\
\hline Chile & Greece & Lithuania & Qatar & Uruguay \\
\hline Colombia & Honduras & Luxembourg & Romania & \\
\hline Croatia & Hungary & Macedonia & Saudi Arabia & \\
\hline Cyprus & Iceland & Malta & Serbia & \\
\hline
\end{tabular}

bility (Hume and Rimstidt, 1992; Bernstein et al., 2008; Oze and Solt 2010). In this work, we summarize and discuss data of the most relevant studies available in literature which testify the presence of asbestos fibres in soils worldwide.

\section{Methods and Materials}

In this work, we carried out a literature search on articles of various disciplines that appeared over the past thirty years and subdivided them according to the source of contamination: i) indirect contamination; and ii) direct contamination (Table 2).

\section{Results and Discussion}

The articles that reveal the presence of asbestos fibres in soils due to indirect contamination are mainly of three types: i) case-report; ii) case-control study; iii) environmental study.

The first two are mainly epidemiological studies based on the investigation of documented cases of pathologies consequently to the occupational and environmental exposition to asbestos. In particular, case-report consists in a detailed description of an individual case whereas case-control study involves the comparison of two existing groups differing in outcome (e.g., effected by issues: case; non-effected: control).

Case- reports and case-control studies involved in the present work, revealed that in most cases the contamination is due to the presence of fibres in materials used for aims like dirt roads (Baris et al., 1987; Viallat et al., 1991; Luce et al., 2000; Comba et al., 2003; Luo et al., 2003), and whitewash (Constantopoulos et al., 1991; Sichletidis et al., 1992; Sakellariou 1996; Luce et al., 2000; Metintas et al., 2002).

For instance, Luce et al. 2000, carried out a study on respiratory cancers in New Caledonia, where a high incidence of malignant pleural mesothelioma had been observed. In particular, a case-control study has been conducted in regard to the association between tremo- lite exposure and the risk for respiratory cancer from different sites. Results revealed that the risk of pleural mesothelioma was associated with exposure to whitewash (Table 3 ) that have widely been used for indoor and outdoor walls of houses.

Differently, the other articles taken into consideration are based on environmental and monitoring study where the source of contamination is mainly represented by asbestos removal operations (Davies et al., 1996; Gualtieri et al., 2009), asbestos in material used for construction (Famoso et al., 2012) or asbestos waste in soil (Driece et al., 2010; Bint et al., 2017), proximity to asbestos mine (Gualtieri et al., 2014; Lee et al., 2015; Turci et al., 2016) as well as asbestos cement factory, widely documented in India (Musthapa et al., 2003; Subramanian et al., 2005; Trivedi et al., 2011, 2013) where the use and production of asbestos is not banned yet.

Gualtieri et al. 2009, presented the results of a monitoring activity conducted on particulate, fall-out and soil samples of selected inhabited areas in Italy (i.e., Emilia Romagna region). The aim of the work was to detect asbestos content in air and the risk of exposure for the population in addition to the assessment of the nature of other mineral phases composing the particulate matrix. To this purpose, various analytical techniques have been used such as XRPD, PLOM, SEM, TEM. In the specific case of the analyzed soils, asbestos fibres were found in samples taken from a residential zone of Sassuolo and near the Bologna Central Railway Station. According to authors, in the first case the contamination is likely due to asbestos removal operations of ACMs whereas in the second case, natural dispersion from ophiolite rock used as track ballast represent the source of contamination. For the results interpretation they elaborate a general model of environmental asbestos pollution (Fig. 2a) referring to the pollution mechanism proposed by Chiappino et al., 1993. The latter consists of a primary and secondary pollution stages. In the primary, the dispersing materials release coarse fibres which settle near to the source because of their higher mass and at the same time release ultra-fine materials. In the secondary, the settled fibres break up into ultra-fine and ultra-short fibrils that are able to remain suspended in the atmosphere for long periods thanks to their minimal mass. 
Table 2. Literature data of asbestos-containing soil

\begin{tabular}{|c|c|c|c|c|}
\hline Place & Fibres type & Source of contamination & Methods & Reference \\
\hline Australia & $\begin{array}{l}\text { Amosite, Crocidolite, } \\
\text { Chrysotile }\end{array}$ & Indirect (ACMs in the soil) & Case - report & Genever et al., 2017 \\
\hline China (Da-yao) & Crocidolite & Indirect (Dirt roads, stucco, dishes) & $\begin{array}{l}\text { Review of clinical/epidemiological } \\
\text { studies }\end{array}$ & Luo et al., 2003 \\
\hline Corsica & Tremolite & Indirect (use in the flooring) & Case - report & Viallat et al., 1991 \\
\hline Cyprus & Tremolite Crisotile & Indirect (Stucco, gutters) & $\begin{array}{l}\text { Case - report } \\
\text { Radiological studies on population }\end{array}$ & McConnochie et al., 1989 \\
\hline Greece & Tremolite, Chrysotile & Indirect (Whitewash) & Case - report XRPD & $\begin{array}{l}\text { Constantopoulos et al., } \\
1991\end{array}$ \\
\hline Greece (Macedonia) & Tremolite, Chrysotile & Indirect (Whitewash) & $\begin{array}{l}\text { Case - report } \\
\text { X-ray study on population }\end{array}$ & Sichletidis et al., 1992 \\
\hline Greece (Metsovo) & Tremolite & Indirect (Whitewash) & $\begin{array}{l}\text { Case - report } \\
\text { X-ray study on population }\end{array}$ & Sakellariou et al., 1996 \\
\hline $\begin{array}{l}\text { India (Mohanlalganj, } \\
\text { Lucknow) }\end{array}$ & Chrysotile & $\begin{array}{l}\text { Indirect (Vicinity to } \\
\text { Asbestos cement factory) }\end{array}$ & PCOM & $\begin{array}{l}\text { Subramanian et al., 2005; } \\
\text { Trivedi et al., 2011, 2013; } \\
\text { Musthapa et al., } 2003\end{array}$ \\
\hline Italy (Basilicata) & Tremolite & Direct (Natural occurrences) & $\begin{array}{l}\text { Case - report; } \\
\text { OM, SEM-EDS, TEM-EDS } \\
\text { XRPD, XRF, DTG, DSC }\end{array}$ & $\begin{array}{l}\text { Bernardini et al., 2003; } \\
\text { Pasetto et al., 2004; } \\
\text { Bloise et al., 2016, 2018; } \\
\text { Punturo et al., 2018, } 2019\end{array}$ \\
\hline Italy (Emilia-Romagna) & Serpentine asbestos & $\begin{array}{l}\text { Indirect (Asbestos removal } \\
\text { operations); Direct (Natural } \\
\text { occurrences) }\end{array}$ & PLOM, XRPD, SEM, TEM & Gualtieri et al., 2009 \\
\hline Italy (Liguria) & $\begin{array}{l}\text { Tremolite, Actinolite, } \\
\text { Chrysotile }\end{array}$ & Direct (Natural occurrences) & SEM-EDS & $\begin{array}{l}\text { Barale et al., 2020; } \\
\text { Militello et al., 2019; } \\
\text { Turci et al., } 2020\end{array}$ \\
\hline Italy (Lombardy) & Chrysotile, Tremolite & Direct (Natural occurrences) & SEM-EDS & Cavallo et al., 2020 \\
\hline Italy (Piedmont) & Chrysotile & Indirect (Vicinity to asbesos mine) & $\mu \mathrm{XRF}, \mathrm{XRPD}, \mathrm{SEM}$ & Turci et al., 2016 \\
\hline Italy (Sicily) & Fluoro-edenite & $\begin{array}{l}\text { Indirect (Quarries, dirt roads, } \\
\text { use in mortar and plasters) }\end{array}$ & Case - report; PCOM, SEM-EDS & $\begin{array}{l}\text { Comba et al., 2003; } \\
\text { Famoso et al., } 2012\end{array}$ \\
\hline Italy (Valle d'Aosta) & Tremolite, Chrysotile & Indirect (Vicinity to asbestos mine) & OM, XRPD, FTIR, SEM, DTA & Gualtieri et al., 2014 \\
\hline $\begin{array}{l}\text { Korea (Hongseong; } \\
\text { Janghang) }\end{array}$ & $\begin{array}{l}\text { Chrysotile, Tremolite, } \\
\text { Actinolite }\end{array}$ & $\begin{array}{l}\text { Indirect (Vicinity to asbestos mine), } \\
\text { Direct (Natural occurrences) }\end{array}$ & $\begin{array}{l}\text { PLM, XRD, PCM, FE-EDS, } \\
\text { SEM-EDS, TEM-EDS }\end{array}$ & $\begin{array}{l}\text { Lee et al., 2015; } \\
\text { Yoon et al., } 2020\end{array}$ \\
\hline $\begin{array}{l}\text { Netherlands } \\
\text { (Hof van Twente) }\end{array}$ & Crocidolite, Chrysotile & Indirect (Asbestos waste in soil) & TEM on air samples & Driece et al., 2010 \\
\hline New Caledonia & Tremolite & Indirect (Whitewash, dirt roads) & Case - control study & $\begin{array}{l}\text { Luce et al., 2000; } \\
\text { Petriglieri et al., 2020b }\end{array}$ \\
\hline New Zeland & Asbestos fibres & Indirect (Construction waste) & Guidelines & Bint et al., 2017 \\
\hline Turkey (Anatolia) & $\begin{array}{l}\text { Tremolite, Actinolite, } \\
\text { Chrysotile }\end{array}$ & $\begin{array}{l}\text { Indirect (Whitewash, stucco, terra- } \\
\text { cotta); Direct (Natural occurrences) }\end{array}$ & Cohort study; XRPD & $\begin{array}{l}\text { Metintas et al., 2002, } \\
2017\end{array}$ \\
\hline Turkey (Cappadocia) & Erionite & Indirect (Dirt roads, brick) & Case - control study & Baris et al., 1987 \\
\hline United Kingdom & Amosite, Crocidolite & Indirect(Asbestos removal operations) & PCOM quantitative study & Davies et al., 1996 \\
\hline USA & Amphibole asbestos & Direct (Natural occurrences) & XRD, SEM & Thompson et al., 2011 \\
\hline USA (California) & $\begin{array}{l}\text { Chrysotile, fibrous } \\
\text { amphiboles }\end{array}$ & Direct (Natural occurrences) & $\begin{array}{l}\text { TEM-EDX Electron diffraction } \\
\text { analysisi }\end{array}$ & Bailey 2020a \\
\hline USA (Nevada) & Actinolite, Fibrous Erionite & Direct (Natural occurrences) & SEM-EDS, FE-SEM, XRD & $\begin{array}{l}\text { Buck et al., 2013; } \\
\text { Ray } 2020\end{array}$ \\
\hline USA (Whashington) & Chrysotile, Actinolite & Direct (Natural occurrences) & PLM & EPA, 2009 \\
\hline
\end{tabular}

Concerning direct contamination, according to the most relevant studies it has been recognized into three countries: Italy, Turkey and USA. In Italy, many studies have been conducted in the Basilicata and Calabria region (Campopiano et al., 2018; Bloise et al., 2019c; Colombino et al., 2019; Dichicco et al., 2019; Laurita and Rizzo, 2019) where tremolite is the main asbestos mineral found in soils (Pasetto et al., 2004; Bloise et al., 2016a; 2018a,b; Punturo et al., 2018, 2019). Tremolite, in actinolite and chrysotile has also been observed in soil sam- ples investigated by Militello et al., 2019 (Liguria region), whereas samples analysed by Gualtieri et al., 2009, testify the presence of serpentine asbestos in soils occurring in Valle d'Aosta region.

For example, the purpose of the study carried out by Bloise et al., 2016a was to assess the occurrence of asbestiform minerals in serpentinite and serpentinite-derived soils cropping out in the area of Sila Piccola. To this aim, they characterized both serpentinite and agricultural soil samples by means of various analytical techniques such as 
Table 3. Pleural mesothelioma risk associated with exposure to whitewash, New Caledonia, 1993-1995. *Odds ratio adjusted for age and gender; $I$ Numbers in parentheses, 95\% confidence interval (Modified after Luce et al., 2000)

\begin{tabular}{cccc}
\hline \hline Exposure & No. of cases & No. of controls & Odds ratio* \\
\hline Never exposed & 1 & 223 & 1 \\
Ever exposed & 14 & 82 & $40,9(5.15,325) \mathrm{f}$ \\
Exposure duration & & 38 & $22.2(2.33,211)$ \\
$<$ 20 years & 4 & 41 & $65.1(7.69,551)$ \\
$\geq 20$ years & 10 & & $52.8(6.53,427)$ \\
Age at first exposure & & 61 & $20.0(1.09,368)$ \\
Birth & 13 & 11 & 0 \\
$\leq 16$ & 1 & 10 & \\
$>16$ & 0 & &
\end{tabular}
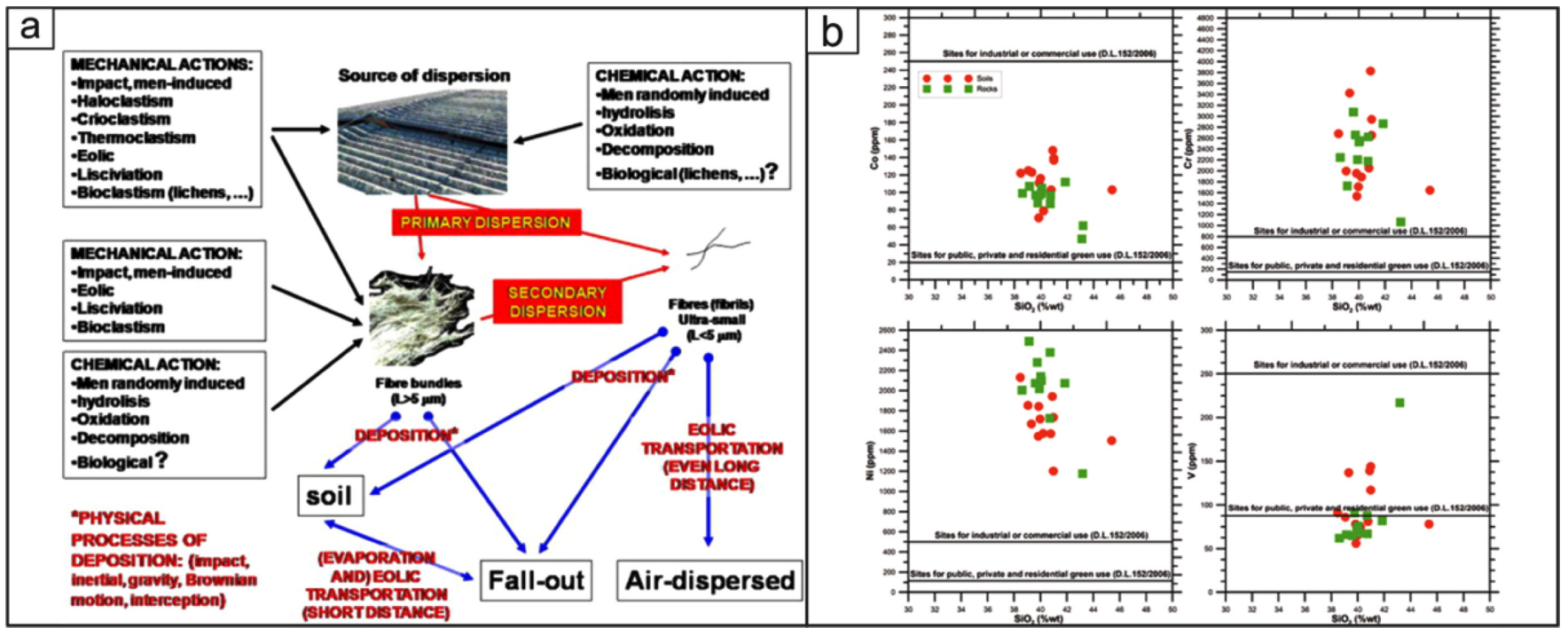

Figure 2. a) Model of asbestos fibre dispersion from cement-asbestos (modified after Gualtieri et al., 2009); b) Correlation diagrams of SiO ${ }_{2}$ versus Co, Cr, Ni and V for soils and rocks of the studied area (after Punturo et al., 2018). Thresholds values regulated by Italian law (D.L.152/2006) are also indicated for each heavy metal.

Table 4. Mineralogical assemblage detected by PLM, XRPD, SEM/EDS, $D S C / T G, \mu-R$ reported in order of decreasing abundance. $P S=$ polygonal serpentine, Atg= antigorite, $L z=$ lizardite, $C t l=$ chrysotile, $T r$-Act=tremoliteactinolite, Mag=magnetite, $C h l=c h l o r i t e, M s=$ muscovite, $A b=a l b i t e, Q t z=q u a r t z$, Cal=calcite, $R t=$ rutile, $S p=$ spinel (Bloise et al., 2016)

\begin{tabular}{cl}
\hline \hline Sample & \multicolumn{1}{c}{ Phase detected } \\
\hline CNF-S1 & Clay $>$ Qtz $>$ Tr - Act $>$ Chl $>$ Ms $>$ Ctl $>$ Liz $>$ Ab $>$ Atg $>$ Rt \\
CNF-S2 & Clay $>$ Qtz $>$ Chl $>$ Ms $>$ Tr - Act $>$ Ctl $>$ Ab $>$ Rt $>$ Liz \\
GML-S1 & Clay $>$ Qtz $>$ Chl $>$ Ms $>$ Tr - Act $>$ Ctl $>$ Ab $>$ Liz $>$ Rt \\
\hline
\end{tabular}

PLOM, XRPD and SEM/EDS. Moreover, for a better discrimination of serpentine polytypes, Differential Scanning Calorimetry, Thermogravimetric and $\mu$-Raman spectroscopy were used. Results show high amount of chrysotile and asbestos tremolite-actinolite in agricultural soils (Table 4).

Instead, Punturo et al. 2018 conducted a detailed mineralogical and geochemical investigation of both rocks and soil collected in the Basilicata region, with the aim to understand their potential contribution to human health caused by asbestos exposure. Therefore, the presence of asbestos fibres (chrysotile and asbestos tremolite) and the concentration levels of toxic elements $(\mathrm{Cr}, \mathrm{Co}, \mathrm{Ni}, \mathrm{V})$ have been determined. In the specific case, in almost all samples, detected values exceed the regulatory thresholds for public, private and residential green use (D.L. 152/2006; Fig. 2b).

In the other two countries, fibrous amphiboles and chrysotile are the main fibres detected. In particular, a total of 1251 soil samples in Anatolia region (Turkey) were collected and analyzed by Metintas et al., 2017 (Fig. 3a). XRPD analysis results revealed that chrysotile, tremolite or mixed asbestos fibres were contained in 514 soil samples.

In USA, high occurrence of actinolite and chrysotile has been monitored (EPA, 2009; Thompson et al., 2011; Buck et al., 2013). Thompson et al., 2011 discussed the geographic distribution of amphiboles in the USA, using the mineralogical data from selected sand and/or silt fraction of soils from the USDA-NRCS National Cooperative Soil Survey database, which shows the presence of amphiboles in all states except for Rhode Island. A total of 212,839 horizons (layer within soil with unique morphological characteristics) within 34,326 pedons (body of soil that consists of all the horizons at that location) were sampled (Fig. 3b). 

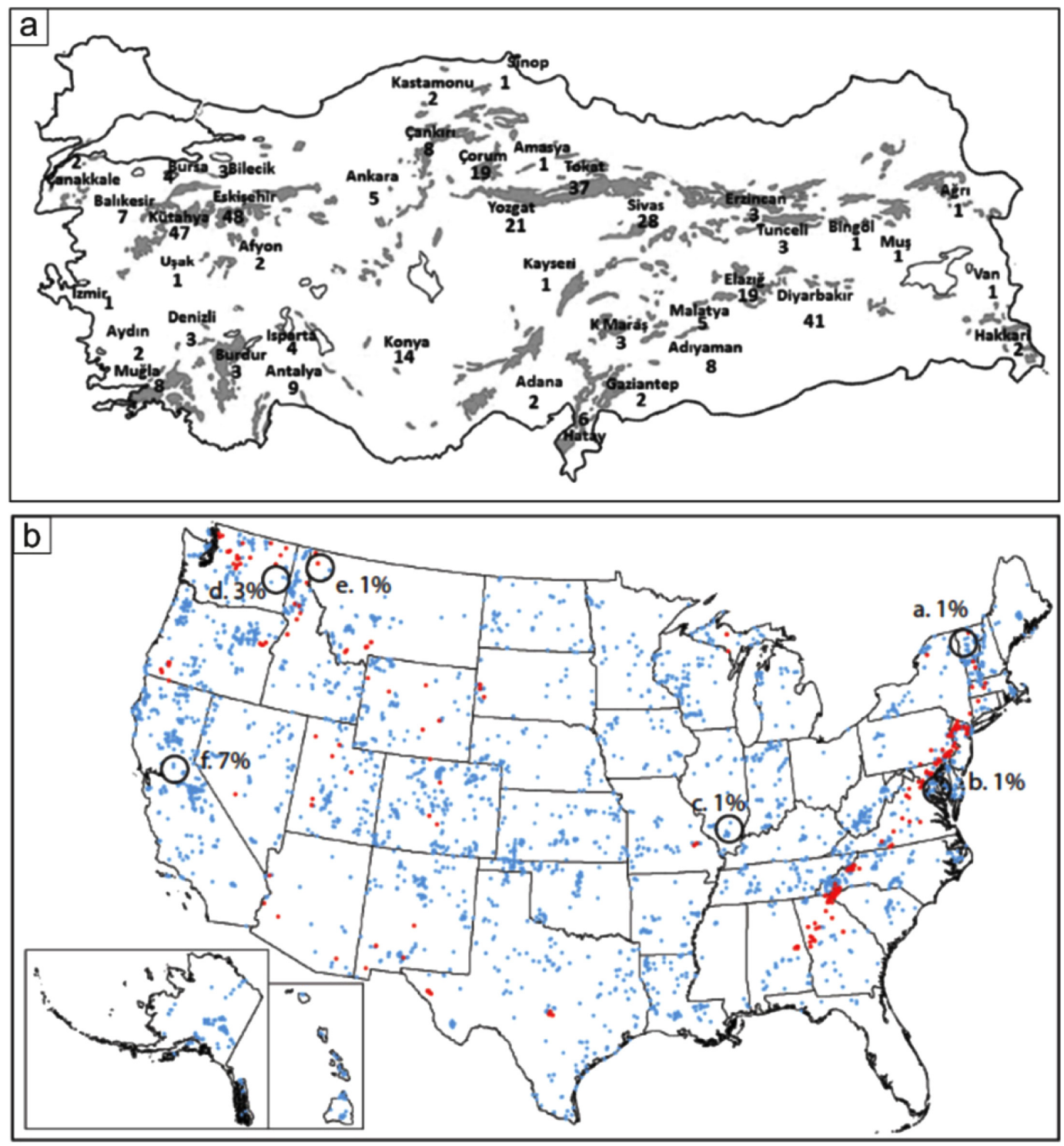

Figure 3. a) Map of Turkey showing the distribution of villages where asbestos exposure was definite (after Metintas et al., 2017; b) Map of the U.S.A. showing asbestos-containing soils (more detail from Thompson et al., 2001))

On the basis of data available in literature of the past thirty years, it is possible to draw up various considerations. First of all, asbestos-related diseases are certainly of significant concern in terms of occupational and public health. Indeed, many studies confirmed a significant malignant mesothelioma risk due to asbestos environmental exposure (Baumann et al., 2016; Liu et al., 2017). Compared to NOA in rocks (Bloise et al., 2019a), asbestos content in soils is today poorly investigated. The soil contamination plays an important role relatively to the environmental exposure especially if soils are used for agricultural purposes, becoming a risk for both workers (Bellomo et al., 2018) and people living near NOA (non-occupational exposure; Bloise et al., 2012; Pugnaloni et al., 2013; Bloise et al., 2017b; Bloise et al., 2018c; Pinizzotto et al., 2018; Punturo et al., 2018). According to Januch et al., 2013, people exposure derived from disturbance of asbestos-contaminated soil, is mainly investigated by measuring asbestos concentration in breathing zone air during soil-disturbance activities. Nevertheless, in our opinion the determination of asbestos content in top-soil or sub-soil is essential as it constitutes the primary threat to health. Indeed, the tendency of fibres is to settle out of air and water and deposit in soil (EPA, 1979). Moreover, some fibres are sufficiently small to remain in suspension and can be transported for long distance thus increasing the contamination area. It is worth specifying that, asbestos itself is very stable and, if not disturbed can remain in the soil indefinitely (ATSDR, 2001). Indeed, concerning ACMs asbestos is bonded in a matrix which does not favour the release of free respirable fibres unless it is extremely weathered, or exposed to acid material (NEPC, 2011). However, many common forms of asbestos containing materials may slowly degrade if left in soil leading to more asbestos fibres being released over time (Bint et al., 2017). Since the extensive use in the past, ACMs represent a persistent source of environmental pollution despite the cessation of asbestos mining and legal prohibitions adopted by many countries. It is estimated that about 150 million $\mathrm{m}^{2}$ of asbestos-based products and more than two thousand million $\mathrm{m}^{2}$ of cement-asbestos roofings are still present today (Gualtieri et al., 2009).

In summary, the source of asbestos contamination in soils can be indirect and direct. In the first case, it is originated by asbestos fac- 


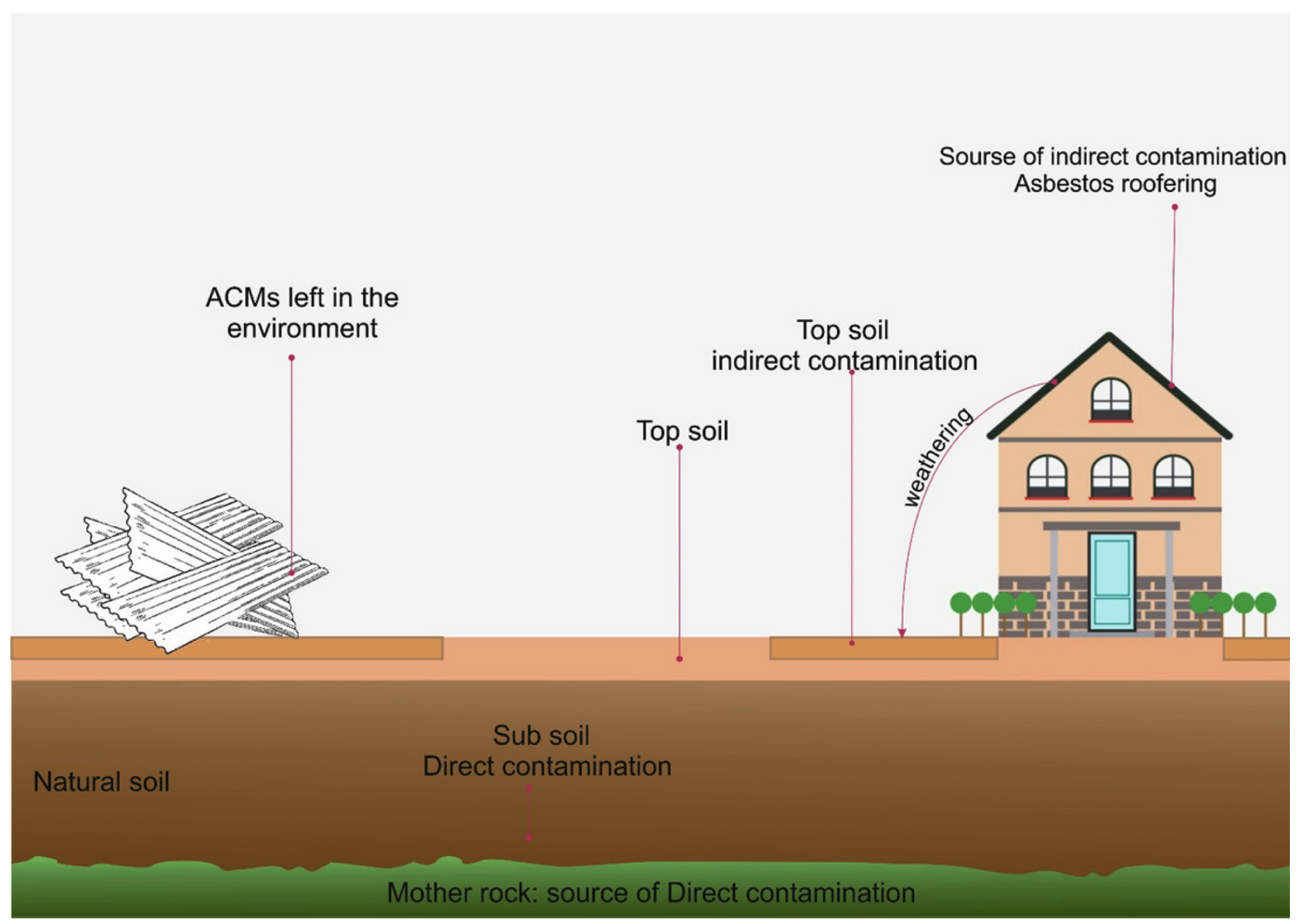

Figure 4. The image shows where asbestos fibres can be found depending on the source of contamination (direct/indirect).

tory, mines and ACMs subject to weathering or improperly removed. Direct contamination instead, derive by the disturbance of natural deposits by weathering or anthropic activity which cause the dispersion of fibres into the environment.

Depending on the source of contamination, asbestos fibres can be found in different portion of soil. Indeed, to verify the presence of fibres in the surrounding of asbestos factory/mine it is important to sample the top-soil in the proximity of the emission point. Differently, in the case of direct contamination, sub-soil samples are more representative since the presence of fibres is not due to deposition but rather to the characteristics of the mother rock. Figure 4, summarize where fibres can be found depending on the contamination source.

Observing the collected data, it is possible to notice that the indirect contamination has been widely detected in the investigated soils and their distribution cover a big range of the territory. This is likely due to the high use and commercialization of asbestos in the past, which resulted in his exportation all over the world.

Instead, since natural asbestos occurrences depends on the geology of the area, the presence of contaminated soils is limited to the distribution of the mother rock outcrops.

In recent years a new line of research asserts that the ingestion of asbestos by drinking water containing fibres, represents another factor that may cause an increase in cancer incidence in expose populations (DHHS Committee, 1987) although this issue is still debated (Rodelsperger et al., 1991; Di, 2017; Li et al., 2019). The possible sources of contamination include erosion of rock, industrial effluents, disintegration of asbestos-containing products (WHO, 2000, 2004). In this context, it is essential to identify the source dispersion and act on it. Therefore, knowledge on contaminated soil as well as territory mapping need to be improved.

\section{Conclusions}

In this study, a detailed examination of the most relevant literature studies revealing the presence of asbestos in soils worldwide, has been conducted. The aim of this work is to provide an overview about the distribution of asbestos-containing soils, thus improving the global mapping and the knowledge obtained so far.

Main results from our investigation showed that the presence of asbestos content in soils is still poorly studied. At this time, many studies are mainly based on the measuring of asbestos concentration in breathing zone air during disturbance activities. Moreover, several studies provide epidemiological and experimental evidence that trace metals may provoke lung cancer thus making necessary their investigation. In this scenario, the identification of the source of contamination and actions on it are essential.

For instance, one way to locate the potential "asbestos-containing soil" is to: i) identify the natural outcrops of rocks that may contain asbestos and investigate on derivative soil (natural contamination); and ii) identify old factory and asbestos mine (even the abandoned ones) and examine the surrounding soil (indirect contamination). As far as ACMs is concerned, it may be more difficult because of their high diffusion all over the world due to the extensive use in the past, but removal or renewal action are essential.

\section{Acknowledgements}

The work has received financial support from University of Calabria and from "Piano Triennale della Ricerca (2017-2020)" (Università 
di Catania, Dipartimento di Scienze Biologiche, Geologiche e Ambientali), scientific responsible Rosalda Punturo.

\section{References}

Agency for Toxic Substances and Disease Registry, 2001, Toxicological profile for asbestos. Division of Toxicology/Toxicology Information Branch, Atlanta, $319 \mathrm{p}$.

Bailey, R.M., 2020a, Asbestiform Minerals of the Franciscan Assemblage in California with a Focus on the Calaveras Dam Replacement Project. Environmental and Engineering Geoscience February 20, v. 26, pp. 21-28. doi.org/10.2113/EEG-2264

Bailey, R.M., 2020b, Overview of Naturally Occurring Asbestos in California and Southwestern Nevada. Environmental and Engineering Geoscience February 20, v. 26, pp. 9-14. doi:org/10.2113/EEG-2282

Ballirano, P., Bloise, A., Cremisini, C., Nardi, E., Montereali, M.R., and Pacella, A., 2018b, Thermally induced behavior of the K-exchanged erionite: a further step in understanding the structural modifications of the erionite group upon heating. Periodico di Mineralogia, v. 87, pp. 123-134.

Ballirano, P., Bloise, A., Gualtieri, A.F., Lezzerini, M., Pacella, A., Perchiazzi, N., Dogan, M., and Dogan, A.U., 2017, The Crystal Structure of Mineral Fibers. In: Gualtieri, A.F., (Eds.), Mineral Fibers: Crystal Chemistry, Chemical-Physical Properties, Biological Interaction and Toxicity. European Mineralogical Union, London, 2017, pp. 17-53.

Ballirano, P., Pacella, A., Bloise, A., Giordani, M., and Mattioli, M., 2018a, Thermal Stability of Woolly Erionite-K and Considerations about the Heat-Induced Behaviour of the Erionite Group. Minerals, v. 8, pp. 28.

Barale, L., Piana, F., Tallone, S., Compagnoni, R., Avataneo, C., Botta S., Marcelli, I., Irace, A., Mosca, P., Cossio, R., and Turci, F., 2020, Geological Model for Naturally Occurring Asbestos Content Prediction in the Rock Excavation of a Long Tunnel (Gronda di Genova Project, NW Italy). Environmental and Engineering Geoscience February 20, v. 26, pp. 107-112. doi:org/10.2113/EEG-2269

Baris, I., Simonato, L., Artvinli, M., Pooley, F., Saracci, R., Skidmore, J., and Wagner, C., 1987, Epidemiological and environmental evidence of the health effects of exposure to erionite fibres: a four-year study in the Cappadocian region of Turkey. International Journal of Cancer, v. 39, pp. 10-17.

Baumann, F., and Carbone, M., 2016, Environmental risk of mesothelioma in the United States: an emerging concern-epidemiological issues. Journal of Toxicology and Environmental Health Part B Critical Reviews, v. 19 , pp. 231-249.

Bellomo, D., Gargano, C., Guercio, A., Punturo, R., and Rimoldi, B., 2018, Workers' risks in asbestos contaminated natural sites. Journal of Mediterranean Earth Sciences, v. 10, pp. 97-106.

Belluso, E., Baronnet, A., and Capella, S., 2020, Naturally Occurring Asbestiform Minerals in Italian Western Alps and in Other Italian Sites. Environmental and Engineering Geoscience February 20, v. 26, pp. 39-46. doi:org/10.2113/EEG-2276

Bernardini, P., Schettino, B., Sperduto, B., Giannandrea, F., Burragato, F., and Castellino, N., 2003, Tre casi di mesotelioma pleurico ed inquinamento ambientale da rocce affioranti di tremolite in Lucania. Giornale Italiano di Medicina del Lavoro ed Ergonomia, v. 25, pp. 408-411.

Bernstein, D.M., Donaldson, K., Decker, U., Gaering, S., Kunzendorf, P., Chevalier, J., and Holm, E., 2008, A biopersistence study following exposure to chrysotile asbestos alone or in combination with fine particles. Inhalation Toxicology, v. 20, pp. 1009-1028.

Bint, L., Hunt, S., Dangerfield, D., and Mechaelis, M., 2017, New Zeland Guidelines for Assessing and Managing Asbestos in soil. Branz, Porirua, $96 \mathrm{p}$.

Bloise, A., 2019a, Thermal behaviour of actinolite asbestos. Journal of Materials Science, v. 54, pp. 11784-11795.

Bloise, A., Barca, D., Gualtieri, A.F., Pollastri, S., and Belluso, E., 2016b,
Trace elements in hazardous mineral fibres. Environmental Pollution, v. 216, pp. 314-323.

Bloise, A., Belluso, E., Critelli, T., Catalano, M., Apollaro, C., Miriello, D., and Barrese, E., 2012, Amphibole asbestos and other fibrous minerals in the meta-basalt of the Gimigliano-Mount Reventino Unit (Calabria, south-Italy). Rendiconti Online della Società Geologica Italiana, v. 21, pp. $847-848$

Bloise, A., Catalano, M., Critelli, T., Apollaro, C., and Miriello, D., 2017b, Naturally occurring asbestos: potential for human exposure, San Severino Lucano (Basilicata, Southern Italy). Environmental Earth Sciences, v. 76, pp. 648.

Bloise, A., Catalano, M., and Gualtieri, A., 2018, Effect of grinding on chrysotile, amosite and crocidolite and implications for thermal treatment. Minerals, v. 8, pp. 135.

Bloise, A., Fornero, E., Belluso, E., Barrese, E., and Rinaudo, C., 2008, Synthesis and characterization of tremolite asbestos fibres. European Journal of Mineralogy, v. 20, pp. 1027-1033.

Bloise, A., Kusiorowski, R., and Gualtieri, A., 2018a, The effect of grinding on tremolite asbestos and anthophyllite asbestos. Minerals, v. 8, pp. 274. doi:org/10.3390/min8070274

Bloise, A., Kusiorowski, R., Lassinantti, Gualtieri, M., and Gualtieri, A.F., 2017a, Thermal behaviour of mineral fibers. In: Gualtieri, A.F. (Eds)., Mineral Fibers: Crystal Chemistry, Chemical-Physical Properties, Biological Interaction and Toxicity; European Mineralogical Union: London, 2017; 18, pp. 215-252.

Bloise, A., and Miriello, D., 2018c, Multi-analytical approach for identifying asbestos minerals in situ. Geosciences, v. 8, pp. 133

Bloise, A., Punturo, R., Catalano, M., Miriello, D., and Cirrincione, R., 2016a, Naturally occurring asbestos (NOA) in rock and soil and relation with human activities: the monitoring example of selected sites in Calabria (southern Italy). Italian Journal of Geosciences, v. 135, pp. 268-279.

Bloise, A., Punturo, R., Kusiorowski, R., and Pereira Gómez, D., 2019a, Editorial for Special Issue "Mineral Fibres". Fibers, v. 7, pp. 54.

Bloise, A., Ricchiuti, A., Giorno, E., Zumpano, P., Miriello, D., Apollaro, C., Crispini, A., De Rosa, R., and Punturo, R., 2019c, Assessment of Naturally Occurring Asbestos in the area of Episcopia (Lucania, Southern Italy). Fibers, v. 7, pp. 703

Bloise, A., Ricchiuti, C., Lanzafame, G., and Punturo, R., 2019b, X-ray synchrotron microtomography: a new technique for characterizing chrysotile asbestos. Science of The Total Environment, v. 703, pp. 135675. doi:org/10.1016/j.scitotenv.2019.135675

Buck, B., Goossens, D., Metcalf, R.V., McLaurin, B., and Freudenberger, M., 2013, Naturally Occurring Asbestos: Potential for Human Exposure, Southern Nevada, USA. Soil Science Society of America Journal, v. 77, pp. 2192-2204.

Cagnard, F., and Lahondère, D., 2020, Naturally Occurring Asbestos in France: Geological Mapping, Mineral Characterization, and Technical Developments. Environmental and Engineering Geoscience February 20, v. 26, pp. 53-59. doi:org/10.2113/EEG-2277

Cahill, E., 2020, Sampling, Analysis, and Risk Assessment for Asbestos and Other Mineral Fibers in Soil. Environmental and Engineering Geoscience February 20, v. 26, pp. 121-127. doi:org/10.2113/EEG-2286

Campopiano, A., Bruno, M., Olori, A., Angelosanto, F., Iannò, A., Casciardi, S., and Spadafora, A., 2018, Fibrous antigorite in mount reventino area of central calabria. Journal of Mediterranean Earth Sciences, v. 10 , pp. $17-25$.

Camus, M., 2001, A ban on asbestos must be based on a comparative risk assessment. Journal of the Association of Medicine Canadian, v. 164, pp. 491-494.

Cardile, V., Lombardo, L., Belluso, E., Panico, A., Capella, S., and Balazy, M., 2007, Toxicity and Carcinogenicity Mechanisms of Fibrous Antigorite. International journal of environmental research and public health, v. 4, pp. 1-9.

Cavallo, A., and Petriglieri, J.R., 2020, Naturally Occurring Asbestos in Valmalenco (Central Alps, Northern Italy): From Quarries and Mines 
to Stream Sediments. Environmental and Engineering Geoscience February 20, v. 26, pp. 47-52. doi:org/10.2113/EEG-2270

Chiappino, G., Todaro, A., and Blanchard, O., 1993. Atmospheric asbestos pollution in the urban environment: Rome, Orbassano and a control locality (II). La medicina del lavoro, v. 84, pp. 187-192.

Colombino, E., Capella, S., Casalinuovo, F., Racco, R., Pruiti, F., Volante, M., Di Marco, V., Belluso, E., and Capucchio, M., 2019. Malignant peritoneal mesothelioma in a boar who lived in Calabria (Italy): Wild animal as sentinel system of human health. Science of the Total Environment, v. 683, pp. 267-274.

Comba, P., Gianfagna, A., and Paoletti, L., 2003, Pleural mesothelioma cases in Biancavilla are related to a new fluoro-edenite fibrous amphibole. Archives of Environmental and Occupational Health, v. 58, pp. 229-232.

Constantopoulos, S., Theodoracopoulos, P., Dascalopoulos, G., Saratzis, N., and Sideris, K., 1991, Metsovo lung outside Metsovo. Chest, v. 99, pp. 1158-1161.

Davies, L.S.T., Wetherill, G.Z., McIntosh, C., McGonagle, C., and Addison, J., 1996, Development and validation of an analytical method to determine the amount of asbestos in soils and loose aggregates. Institute of Occupational Medicine, Edinburgh, 69 p.

DHHS Committee, 1987, Report on cancer risks associated with the ingestion of asbestos. DHHS Committee to Coordinate Environmental and Related Programs Environmental health perspectives, v. 72, pp. 253265.

Di Ciaula, A., 2017, Asbestos ingestion and gastrointestinal cancer: A possible underestimated hazard. Expert Review of Gastroenterology and Hepatology, v. 11, pp. 419-425.

Driece, H., Siesling, S., Swuste, P., and Burdorf, A., 2010, Assessment of cancer risks due to environmental exposure to asbestos. Journal of Exposure Science and Environmental Epidemiology, v. 20, pp. 478-485.

EPA, 1979, Water-related environmental fate of 129 priority pollutants. Vol I. Introduction and technical background, metals and inorganics, pesticides and PCBs. Washington, DC: U.S. Environmental Protection Agency, Office of Water Planning and Standards. EPA-440/4-79-029a. NTIS No. PB80-204373

EPA, 2009, Soil, Sediment and Surface Water sampling Sumas Mountain Naturally-Occurring Asbestos site, Whatcom county, Washington. U.s. EPA region 10 Office of Environmental Assessment, Seattle, 981013140

Erskine, B.G., 2020, Geologic Investigations for Compliance with the CARB Asbestos ATCM. Environmental and Engineering Geoscience February 20, v. 26, pp. 99-106. doi:org/10.2113/EEG-2290

Famoso, D., Mangiameli, M., Roccaro, P., Mussumeci, G., and Vagliasindi, F., 2012, Asbestiform fibers in the Biancavilla site of national interest (Sicily, Italy): Review of environmental data via GIS platforms. Reviews in Environmental Science and Bio/Technology, v. 11, pp. 417-427.

Genever, M., Allan, M., and Bos, S., 2017, Case studies of contaminated land, final report.

Gianfagna, A., Ballirano, P., Bellatreccia, F., Bruni, B., Paoletti, E., and Oberti, R., 2003, Characterization of amphibole fibers linked to mesothelioma in the area of Biancavilla, eastern Sicily, Italy. Mineralogical Magazine, v. 67, pp. 1221-1229.

Gualtieri A., Pollastri, S., Gandolfi, N., Ronchetti, F., Albonico, C., Cavallo, A., Zanetti, G., Marini, P., and Sala, O., 2014, Determination of the concentration of asbestos minerals in highly contaminated mine tailings: An example from abandoned mine waste of Crètaz and Ėmarese (Valle d'Aosta, Italy). American Mineralogist, v. 99. pp. 1233-1247

Gualtieri, A., Mangano, D., Gualtieri, M., Ricchi, A., Foresti, E., Lesci, G., Roveri, N., Mariotti, M., and Pecchini, G., 2009, Ambient monitoring of asbestos in selected Italian living areas. Journal of Environmental Management, v. 90, pp. 3540-3552.

Gualtieri, A., 2017, Mineral fibres: Crystal chemistry, chemical-physical properties, biological interaction and toxicity. In: A.F. Gualtieri (Eds.), Mineralogical Society, EMU Notes in Mineralogy Volume 18 - chapter 1. Gualtieri, A., Gandolfi, N.B., Passaglia, E., Pollastri, S., Mattioli, M.,
Giordani, M., Ottaviani, M.F., Cangiotti, M., Bloise, A., Barca, D., Vigliaturo, R., Viani, A., Pasquali, L., and Gualtieri, L.M., 2018b, Is fibrous ferrierite a potential health hazard? Characterization and comparison with fibrous erionite. American Mineralogist: Journal of Earth and Planetary Materials, v. 103, pp. 1044-1055.

Gualtieri, A.F., 2020, Naturally Occurring Asbestos: A Global Health Concern? State of the Art and Open Issues. Environmental and Engineering Geoscience February 20, v. 26, pp. 3-8. doi:org/10.2113/EEG2271

Harper, M., 2008, 10th Anniversary critical review: naturally occurring asbestos. Journal of Environmental Monitoring, v. 10, pp. 1394-1408.

Hodgson, J., Darnton, A., 2000, The quantitative risks of mesothelioma and lung cancer in relation to asbestos exposure. Annals of Occupational Hygiene, v. 44, pp. 565-601. doi:org/10.1016/S0003-4878(01)00029-1

Hume, L., and Rimstidt, J., 1992, The biodurability of chrysotile asbestos. American Mineralogist, v. 77, pp. 1125-1128.

International Agency for Research on Cancer, 2009, Asbestos (chrysotile, amosite, crocidolite, tremolite, actinolite, and anthophyllite) IARC Monographs. Arsenic, Metals, fibres and dusts, International Agency for Research on Cancer, Lyon, pp. 147-167.

International Agency for Research on Cancer, 2012, Asbestos (chrysotile, amosite, crocidolite, tremolite, actinolite, and anthophyllite). IARC Monographs on the Evaluation of Carcinogenic Risks to Human, Lyon, France, v. 100C, pp. 219-309.

International Ban Asbestos Secretariat, 2019. http://www.ibasecretariat. org/alpha_ban_list.php

Januch, J., Brattin, W., Woodburyc, L., and Berry, D., 2013, Evaluation of a fluidized bed asbestos segregator preparation method for the analysis of low-levels of asbestos in soil and other solid media. Analytical Methods, v. 5, p. 1658-1668.

Laurita, S., and Rizzo, G., 2019, The first occurrence of asbestiform magnesio-riebeckite in schists in the frido unit (pollino unesco global geopark, southern italy). Fibers, v. 7, pp. 79.

Lee, Jieun., Yoon, C., Ham, S., and Tsai, P., 2015, Optimal Treatment Condition for Changing Characteristics of Naturally Occurring Asbestos. Aerosol and Air Quality Research, v. 15, pp. 2332-2345.

Léocat, E., 2020, Naturally Occurring Asbestos in France: A Technical and Regulatory Review. Environmental and Engineering Geoscience February 20, v. 26, pp. 61-65. doi:org/10.2113/EEG-2254

Li, J., Li, H., Zheng, B., and Yu, Z., 2019, Comparison of analysis of asbestos fibres in drinking water using phase contrast microscopy and microFTIR spectrometry with scanning electron microscopy and energy-dispersive X-ray spectroscopy. Environmental Science: Water Research and Technology, v. 5, pp. 543-551.

Liddell, F.D.K., McDonald, A.D., and McDonald, J.C., 1997, The 18911920 birth cohort of Quebec chrysotile miners and millers: development from 1904 and mortality to 1992. Annals of Occupational Hygiene, v. 41, pp. 13-36.

Liu, B., Van Gerwen M., Bonassi, S., and Taioli, E., 2017, Epidemiology of environmental exposure and malignant mesothelioma. Journal of thoracic oncology: official publication of the International Association for the Study of Lung Cancer Mesothelioma, v. 12, pp. 1031-1045.

Luce, D., Bugel, I., Goldberg, P., Goldberg, M., Salomon, C., Billon- Galland, M., Nicolau, J., Quénel, P., Fevotte, J., and Brochard, P., 2000, Environmental exposure to tremolite and respiratory cancer in New Caledonia: a case-control study. American Hournal of Epidemiology, v. 151, pp. 259-265.

Luo, S., Liu, X., Tsai, S.P., and Wen, C., 2003, Asbestos related diseases from environmental exposure to crocidolite in Da-yao, China. I. Review of exposure and epidemiological data. Occupational and Environmental Medicine, v. 60, pp. 35-42. doi:org/10.1136/oem.60.1.35

McConnochie, K., Simonato, L., Mavrides, P., Christofides, P., Mitha, R., Griffiths, D., and Wagner, J., 1989, Mesothelioma in Cyprus. In: Mignon J, Peto J, Saracci R (Ed.). Non-occupational exposure to mineral fibres. IARC, Science Publications, v. 90, pp. 411-419. 
McDonald, A.D., Case, B.W., Churg, A., Dufresne, A., Gibbs, G.W., Sébastien, P., and McDonald, J.C., 1997, Mesothelioma in Quebec chrysotile miners and millers: epidemiology and etiology. Annals of Occupational Hygiene, v. 41, pp. 707-719

Metintas, S., Batirel, H., Bayram, H., Yilmaz, U., Karadag, M., Ak, G., and Metintas, M., 2017, Turkey National Mesothelioma Surveillance and Environmental Asbestos Exposure Control Program. International Journal of Environmental Research and Public Health, v. 14, pp. E1293.

Metintas, S., Metintas, M., Ucgun, I., and Oner, U., 2002, Malignant mesothelioma due to environmental exposure to asbestos. Chest, v. 122, pp. 2224-2229.

Militello, G., Sanguineti, E., Gonzalez, A., Mantovani, F., and Gaggero, L., 2019, The concentration of asbestos fibers in bulk samples and its variation with grain size. Minerals, v. 9.

Musthapa, M., Ahmad, I., Trivedi, A., and Rahman, Q., 2003. Asbestos contamination in biota and abiota in the vicinity of asbestos-cement factory. Bulletin of Environmental Contamination and Toxicology, v. 70, pp. $1170-1177$.

National Environment Protection Council, 2011, Guideline on investigation levels for soil and groundwater, Assessment of Site Contamination, Measure April 2011, Schedule B1, Adelaide, p. 61

NIOSH, 2008, Current Intelligence Bulletin (June 2008-Revised Draft) Asbestos and Other Elongated Mineral Particles: State of the Science and Roadmap for Research.

Oze, C., and Solt, K., 2010, Biodurability of chrysotile and tremolite asbestos in simulated lung and gastric fluids. American Mineralogist, v. 95, pp. 825-831.

Pasetto, R., Bruni, B., Bruno, C., and Cauzillo, G., 2004, Mesotelioma pleurico ed esposizione ambientale a fibre minerali: Il caso di un'area rurale in Basilicata. Annali Dell'Istituto Superiore Di Sanita, v. 40, pp. 251-265.

Petriglieri, J., Laporte-Magoni, C., Gunkel-Grillon, P., Tribaudino, M., Bersani, D., Sala, O., and Salvioli-Mariani, E., 2020, Mineral fibres and environmental monitoring: A comparison of different analytical strategies in New Caledonia. Geoscience Frontiers, v. 11, pp. 189-202.

Petriglieri, J.R., Laporte-Mangoni, C., Salvioli-Mariani, E., Tomatis, M., Gazzano, E., Turci, F., Cavallo, A., and Fubini, B., 2020b, Identification and Preliminary Toxicological Assessment of a Non-Regulated Mineral Fiber: Fibrous Antigorite from New Caledonia. Environmental and Engineering Geoscience February 20, v. 26, pp. 89-97. doi:org/ 10.2113/EEG-2274

Pierdzig, S., 2020, Regulations Concerning Naturally Occurring Asbestos (NOA) in Germany-Testing Procedures for Asbestos. Environmental and Engineering Geoscience February 20, v. 26, pp. 67-71. doi:org/ 10.2113/EEG-2278

Pinizzotto, M., Cantaro, C., Caruso, M., Chiarenza, L., Petralia, C., Turrisi, S., and Brancato, A., 2018. Environmental monitoring of airborne fluoro-edenite fibrous amphibole in biancavilla (sicily, italy): A nine-years survey. Journal of Mediterranean Earth Sciences, v. 10, pp. 89-95.

Pollastri, S., Gualtieri, A., Lassinantti Gualtieri, M., Hanuskova, M., Cavallo, A., and Gaudino, G., 2014, The zeta potential of mineral fibres. Journal of Hazardous Materials, v. 276, pp. 469-479.

Pugnaloni, A., Giantomassi, F., Lucarini, G., Capella, S., Bloise, A., Di Primio, R., and Belluso, E., 2013, Cytotoxicity induced by exposure to natural and synthetic tremolite asbestos: An in vitro pilot study. Acta histochemical, v. 115, pp. 100-112.

Punturo, R., Ricchiuti, C., and Bloise, A., 2019, Assessment of Serpentine Group Minerals in Soils: A Case Study from The Village of San Severino Lucano (Basilicata, Southern Italy). Fibers, v. 7, pp. 18.

Punturo, R., Ricchiuti, C., Mengel, K., Apollaro., C., De Rosa, R., and Bloise, A., 2018, Serpentinite-derived soils in southern Italy: potential for hazardous exposure. Journal of Mediterranean Earth Sciences, v. 10.

Ray, R., 2020, Discerning Erionite from Other Zeolite Minerals During Analysis. Environmental and Engineering Geoscience February 20, v.
26, pp. 133-139. doi:org/10.2113/EEG-2279

Rodelsperger, K., and Woitowitz, H., 1991, Asbestos in drinking water. Deutsche Medizinische Wochenschrift, v. 116, pp. 555-557.

Ross, M., and Nolan, R.P., 2003, History of asbestos discovery and use and asbestos-related disease in context with the occurrence of asbestos within ophiolite complexes. In: Dilek, Y., Newcomb, S. (Eds.), Ophiolite concept and the evolution of geological thought. Boulder, Colorado, Geological Society of America, Special Paper 373, pp. 447-470.

Sakellariou, K., Malamou-Mitsi, V., Haritou, A., Koumpaniou, C., Stachouli, C., Dimoliatis, I., and Constantopoulos, S., 1996, Malignant pleural mesothelioma from non-occupational asbestos exposure in Metsovo (north-west Greece): slow end of an epidemic? European Respiratory Journal, v. 9, pp. 1206-1210.

Sichletidis, I., Daskalopoulou, E., Tsarou, V., Pnevmatikos, I., Chloros, D., and Vamvalis, C., 1992, Five cases of pleural mesothelioma with endemic pleural calcifications in a rural area in Greece. La Medicina del lavoro, v. 83, pp. 326-329.

Subramanian, V., and Madhavan, N., 2005, Asbestos problem in India. Lung Cancer, v. 49 Suppl 1, pp. S9-12.

Thompson, B.D., Gunter, M.E., and Wilson, M.S., 2011, Amphibole asbestos soil contamination in the USA: A matter of definition. American Mineralogist, v. 96, pp. 690-693.

Trivedi, A., and Ahmad, I., 2011, Effects of Chrysotile Asbestos Contaminated Soil on Crop Plants. Soil and Sediment Contamination, v. 20, pp. 767-776.

Trivedi, A., and Ahmad, I., 2013, Impact of chrysotile asbestos contaminated soil on foliar nutrient status of plants. Indian Journal of Plant Physiology, v. 18, doi:org/10.1007/s40502-013-0036-9

Turci, F., Avataneo, C., Botta, S., Marcelli, I., Barale, L., Tomatis, M., Cossio, R., Tallone, S., Piana, F., and Compagnoni, R., 2020, New Tools for the Evaluation of Asbestos-Related Risk during Excavation in an NOA-Rich Geological Setting. Environmental and Engineering Geoscience February 20, v. 26, pp. 113-120. doi:org/10.2113/EEG-2272

Turci, F., Favero-Longo, S., Gazzano, C., Tomatis, M., Gentile-Garofalo, L., and Bergamini, M., 2016, Assessment of asbestos exposure during a simulated agricultural activity in the proximity of the former asbestos mine of Balangero, Italy. Journal of hazardous, v. 308, pp. 321-327. doi:org/10.1016/j.jhazmat.2016.01.056

Viallat, J., Boutin, C., Steinbauer, J., Gaudichet, A., and Dufour, G., 1991, Pleural effects of environmental asbestos pollution in Corsica. Annals of the Bew York Academy of Sciences 643 (1 The Third Wav), pp. 438-443.

Virta, R., 2002, Asbestos: Geology, Mineralogy, Mining, and Uses. U.S. Geological Survey Open-File Report 02-149, 35 p.

Virta, R., 2006. Worldwide asbestos supply and consumption trends from 1900 through 2003. U.S. Geological Survery Circular 1298, 80 p.

WHO, 2000, Air quality guidelines for Europe (2nd edition). Regional Office for Europe. World Health Organization, Copenhagen, 274 p.

WHO, 2004, Guidelines for Drinking-Water Quality: Third edition. Volume 1, Recommendations. World Health Organization, Geneva, 494 p.

WHO, 1986, Asbestos and other natural mineral fibres. Programme on Chemical Safety. World Health Organization. Environmental Health Criteria 53, Geneva.

Wroble, J., Frederick, T., and Vallero, D., 2020, Refinement of Sampling and Analysis Techniques for Asbestos in Soil. Environmental and Engineering Geoscience February 20, v. 26, pp. 129-131. doi:org/10.2113/ EEG-2283

Yarborough, C., 2007, The risk of mesothelioma from exposure to chrysotile asbestos. Current opinion in pulmonary medicine, v. 13, pp. 334 338.

Yoon, S., Yeom, K., Kim, Y., Park, B., Park, J., Kim, H., Jeong, H., and Roh, Y., 2020, Management of Naturally Occurring Asbestos Area in Republic of Korea. Environmental and Engineering Geoscience February 20, v. 26, pp. 79-87. doi:org/10.2113/EEG-2287 


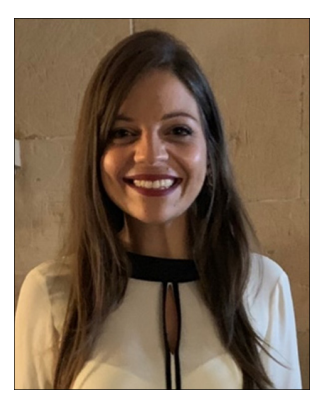

Claudia Ricchiuti is currently a Ph.D. student in mineralogy and petrography at the Department of Biological, Geological and Environmental Sciences at the University of Catania, Italy. Her scientific activity is mainly based on the mineralogical characterization of asbestos fibres in rocks and soils. Since 2015, she improved their knowledge concerning Natural Occurring Asbestos (NOA), through her Master thesis, post-graduated internship at foreign Universities and collaboration with national and international research centres during which she had experience on performing various laboratory analyses (i.e., XRPD, SEM, TEM, TG/DSC, EPMA). She is co-author in scientific international publications, based on petrographic and geochemical investigation of soils and rocks outcropping in southern Apennines with special regards on fibrous minerals.

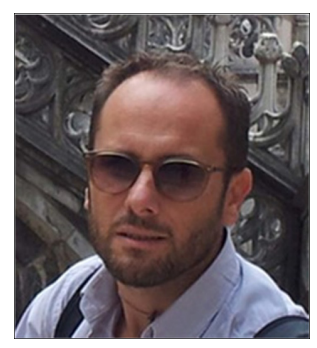

Andrea Bloise is currently Associate Professor of mineralogy at the Department of Biology, Ecology and Earth Sciences (DiBEST) at Calabria University, Rende, Italy. He has expertise in X-ray powder diffraction, scanning and transmission electron microscopy, thermal analysis, collaborating on various scientific projects of national and international interest. He has recently also been working in the fields of cultural heritage and geochemical modelling of both natural and thermal waters. He is the author of several international peer reviewed scientific publications and scientific director of the Laboratory of Experimental Mineralogy at the DiBEST.

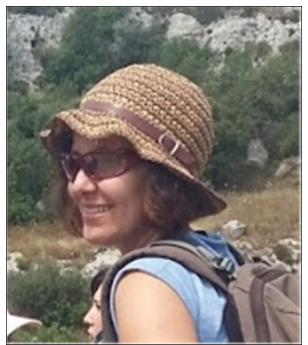

Rosalda Punturo has research interest in Petrography and Petrophysics and their application to cultural heritage and to environment. She completed her doctoral research on petrophysical properties of mantle and crustal xenoliths in the year 2000. Since 2004 she is an assistant Professor at the University of Catania and is part of the group with special focus on Metamorphic, Igneous and Sedimentary petrology. She is the principal investigator of the group focusing on Natural Asbestos Occurrences. She has extensively carried out research in southern Italy (Calabrian-Peloritani Orogen; Hyblean Plateau) and in southern Rhodope Massif(Greece). Official Homepage http://www.dipbiogeo.unict.it/docenti/rosalda. punturo 